Marquette University

e-Publications@Marquette

College of Nursing Faculty Research and

Publications

Nursing, College of

4-2013

\title{
Lack of Father Involvement in Research on Children with Autism Spectrum Disorder: Maternal Parenting Stress and Family Functioning
}

Norah L. Johnson

Marquette University, norah.johnson@marquette.edu

Pippa Simpson

Medical College of Wisconsin

Follow this and additional works at: https://epublications.marquette.edu/nursing_fac

Part of the Nursing Commons

\section{Recommended Citation}

Johnson, Norah L. and Simpson, Pippa, "Lack of Father Involvement in Research on Children with Autism Spectrum Disorder: Maternal Parenting Stress and Family Functioning" (2013). College of Nursing Faculty Research and Publications. 174.

https://epublications.marquette.edu/nursing_fac/174 
Marquette University

e-Publications@Marquette

\section{Nursing Faculty Research and Publications/College of Nursing}

This paper is NOT THE PUBLISHED VERSION; but the author's final, peer-reviewed manuscript. The published version may be accessed by following the link in the citation below.

Issues in Mental Health Nursing, Vol. 34, No. 4 (2013): 220-228. DOI. This article is (C) Taylor \& Francis and permission has been granted for this version to appear in e-Publications@Marquette. Taylor \& Francis does not grant permission for this article to be further copied/distributed or hosted elsewhere without the express permission from Taylor \& Francis.

\section{Lack of Father Involvement in Research on Children with Autism Spectrum Disorder: Maternal Parenting Stress and Family Functioning}

Norah L. Johnson

Marquette University, College of Nursing, Milwaukee, WI

Pippa M. Simpson

Department of Pediatrics and Surgery, Medical College of Wisconsin, Milwaukee, WI

\section{Abstract}

Autism Spectrum Disorder (ASD) has an estimated prevalence of greater than $1 \%$ of people in the US. Caring for children with ASD is stressful and challenging for parents. The purpose of the study is to understand the ramifications of the findings of a spouse/father's lack of participation for a study focused on stress and family functioning that attempted to recruit both parents of a child with ASD. The Kruskal-Wallis test compared medians of three groups of mothers of children with ASD in order to 
assess differences in parenting stress and family functioning discrepancy depending on their marital status and spouse survey participation. There were differences across the groups of mothers of children with ASD for the discrepancy in expectations for help, from the participants' spouse or relatives, with family tasks, meeting the demands of other work responsibilities, child care, challenging behaviors, and school absences. Mothers of children with ASD are at risk for isolation and stress from negotiating family functions with the fathers of the children. Health care providers can assess for stress and family functioning and may anticipate different needs based on marital status and by father's involvement in decision-making.

Autism spectrum disorder (ASD) is a chronic neurodevelopmental disorder of communication, behavior, and socialization, with typical onset occurring before three years of age (American Psychiatric Association, 2000). Four times more common in boys than girls, the prevalence of ASD is increasing and is now estimated to be $1 / 88$ people ( $>1 \%$ of the US population) (Autism and Developmental Disabilities Monitoring Network Surveillance Principal Investigators, 2012). Persons with ASDs present with a range in severity of symptoms with the cause thought to be a combination of genetic predisposition and environmental factors (Hallmayer et al., 2011; Rutter, 2005). Although ASD is not curable, there are several treatment options with a range of evidence to support them (Agency for Healthcare Research and Quality [AHRQ], 2011).

\section{BACKGROUND}

The selection of treatments and the decision making about the day-to-day care of children with ASD typically involves negotiation by both parents. However, often only the mother's perspective is represented in literature. Since mothers and fathers of a child may have different appraisals of their child's treatment needs, the parents' different appraisals can be a source of stress for parents and a cause of unease and potential arguments (Johnson, Frenn, Feetham, \& Simpson, 2011; Knafl \& Deatrick, 2003; Smith, et al., 2010). The lack of parental agreement may not be revealed as a source of stress if fathers do not participate in studies in equal numbers to mothers. Furthermore, both parents may be stressed, which places them both at risk for poor mental health outcomes (Estes, Munson, Dawson, Koehler, Zhou, \& Abbott, 2009; Johnson et al., 2011; Phetrasuwan \& Miles, 2009) and complicates their ability to make the sound decisions about treatments and other aspects of day-today care for the child, which ultimately impacts the child's developmental progress.

\section{FRAMEWORK}

How parents cope with the stress of negotiating needed care and following through with the care varies from parent to parent. Stress and coping theory predicts that people individually appraise their own stress and then cope (Lazarus, 1999). The self-appraisal of stress has implications for mental health. Stress can be buffered if one feels supported from a social network because the stressor may seem less threatening or because other people may provide resources useful for coping with the stress (Lazarus, 1999). Resilient parents are most able to cope with stress, and social support is considered to be a key factor that aids family resiliency (McCubbin, Thompson, \& McCubbin, 1996). Social relationships, for example with spouses or partners, may provide the emotional and informational support that help parents cope (Cohen, Underwood, \& Gottlieb, 2000). Furthermore, social 
relationships are thought to influence cognitions, emotions, and biology (Lakey, 2010; Lakey \& Cohen, 2000). As such, social relationships are positively related to healthy outcomes for parents, such as emotional well-being for parents experiencing stress (Lakey \& Cronin, 2008).

\section{PARENTING STRESS}

Parenting a child with ASD is reported to be more stressful than parenting other children, with mothers perceiving more stress than fathers in three studies (Little, 2002; Hastings et al., 2005; Herring, Gray, Taffe, Sweeny, \& Einfeld et al., 2006). The child's challenging behavior was the main stressor for mothers (Phetrasuwan \& Miles, 2009; Tobing \& Glenwick, 2006). Furthermore, mothers with children with ASD noted more stress and more behavioral outbursts than mothers of other developmentally delayed children (Estes et al., 2009). The mothers' stress may be related to the extra time they spend with children, providing child care and doing chores, thus leaving less time for leisure activities, when compared to mothers of children without disabilities (Smith, Hong, Seltzer, Greenberg, Almeida, \& Bishop, 2010).

In research where both the father and the mother participate, relationship variables were associated with parenting stress. In the first study, marital quality ( $n=88$ married couples) was associated with an increased ability for parents to cope with stress (Siman-Tov \& Kaniel, 2011). In the second study, mothers ( $n=67$ father-mother dyads) with a high perception of a quality marriage reported lower parenting stress as well as fewer depressive symptoms (above and beyond socioeconomic status, child characteristics, and social support) than those reporting low marital quality (Kersh, Hedvat, HauserCram \& Warfield, 2006). Thus, it appears relationship variables may mediate the child with autism's characteristics and parental stress and mental health.

When parents are stressed and feel unsupported, they are at risk for using maladaptive behavior strategies such as avoidance. For example, mothers may ignore a child's behavior and isolate themselves in the home with the child (Gray, 2003). Isolating behaviors may lead to mental health problems (Allik, Larsson, \& Smedje, 2006; Phetrasuwan \& Miles, 2009). In one qualitative study, nine Asian immigrant mothers of children with ASD, without other family supports, reported that school served as a source of support (Luong, Yoder, \& Canham, 2009). Seeking support from outside sources, such as in the community, when not available from the immediate family, is an effective strategy for dealing with stress (Lazarus, 1999) and is an indication of healthy family functioning.

\section{FAMILY FUNCTIONING}

Family functioning can be defined as a set of basic attributes that describe and explain how a family system typically appraises, operates, or behaves (McCubbin \& Thompson, 1991). Family functioning includes supportive relationships among parents, family members, friends, and community members (Roberts \& Feetham, 1982). Rao and Beidel (2009) found that when parents of children with ASD (Asperger's; $n=15$ ) are compared to parents of children with typical development $(n=15)$, the parents of the children with ASD had more stress and family functioning problems. However, family is the first place mothers tend to look for assistance. In fact, in an Easter Seals (2009) study, mothers of children with ASD ( $n=1519$ mothers, $n=133$ fathers) reported that they first look for emotional support, respite, and assistance with family functions from family members. Therefore, families with poor family functioning are missing an important source of support for mothers. 
The child's characteristics, such as his or her behavior problems, may be one reason for the lack of spousal support. For example, in Brobst, Clopton, and Hendrick's (2009) study, mothers of children with ASD with behavior problems $(n=25)$ reported less spousal support than mothers of children with developmental disabilities who had fewer behavior problems $(n=20)$. Research studies that collect data from both parents generally inform intervention strategies included in a family therapy program. However, for parents of children with ASD, studies that attempt to recruit both parents in the parental dyad to answer separate questionnaires have had difficulty in recruiting fathers. Moreover, there is a gap in the literature on the ramifications of interpreting this mother-only data, as a group, without taking into account whether their respective spouse was asked to participate in the study and chose not to. There may be a difference in parenting stress and family functioning across groups of mothers whose spouses do or do not choose to participate.

We know that social relationships with spouses or partners provide the emotional and informational support that help parents cope and foster mental health that best prepares them to care for children for optimal child development outcomes. However, much of the research underpinning what is known about social relationships is from the mothers' perspective, and the difference in perspectives among mothers with participating spouses compared to those without participating fathers' is still unknown, representing a gap. Additionally, studies on stress and family functioning for parents of children with autism may have potential biases. For example, it is important to consider funding sources for studies when interpreting their results. For example, potential bias might exist in the Easter Seals' (2009) study, that had a mainly female sample and which was funded by an insurance company (Mass Mutual). Thus, the present study attempted to address the identified gap in the literature.

\section{PURPOSE}

The purpose of the present study was to understand the ramifications of a spouse/father's lack of participation in a study focused on stress and family functioning, which attempted to recruit both parents of a child with ASD. The study compares the responses about parenting stress and the discrepancy between "what is" and "what should be" for family functioning for mothers of children with ASD grouped by marital status and spouse participation in the study. Using the discrepancy in family functioning allowed for a measure of the parent's appraisal of how much help the parent felt was needed, compared to how much was received. As part of a larger study, separate data were solicited from both parents ( $n=261$ mothers, $n=86$ fathers) of children with ASD. In the larger study (Johnson, Frenn, Feetham, \& Simpson, 2011), both parents were asked to fill out separate questionnaires, but more mothers than fathers completed the request. No information was available to explain why fewer fathers than mothers completed surveys in the larger study. However, it is interesting that in many autism studies that attempt to recruit both parents, more often than not, the majority of participants are mothers. This discrepancy in father participants is similar for other pediatric problems (Macfadyen, Swallow, Santacroce, \& Lambert, 2011). Hearing the father's voice provides a more comprehensive picture of the family experience.

Only the data from the mothers were used in the present study, in order to compare the data of mothers whose spouse (father of the child with ASD) did or did not agree to be part of the larger study. Because some of the mothers were married and others were not, data were grouped by marital status in addition to whether or not the spouse participated. There were three groups: (1) married mothers 
whose male spouses did not participate in the study, (2) married mothers whose spouses did participate in the study and (3) unmarried mothers with no participating spouse/partner.

\section{RESEARCH QUESTIONS}

The aim of the study was to discern if there were differences in maternal stressors and expectations about family functions based on marital status and spouse/partner participation in the surveys in the larger study reported elsewhere in the literature (Johnson, Frenn, Feetham, \& Simpson, 2011). The research questions were: (1) Do married mothers whose male spouses/partners did not participate in the study have lower stress than married or unmarried mothers whose spouses/partners did participate in the study? and (2) do married mothers whose male spouses/partners did participate in the study have higher discrepancy in family functioning than the married or unmarried mothers whose spouses/partners did not participate in the study?

\section{METHODS}

\section{Participants}

A comparative, cross sectional study design was used. Sampling was by convenience. As part of the larger study, recruitment was through flyers on the Interactive Autism Network (IAN) at the Kennedy Krieger Institute sponsored by Autism Speaks, an ASD focus list serve, local autism societies, conferences, and pediatric hospital clinics. The IAN registry allows for an efficient method for participant recruitment. Members of the IAN registry have parent-report diagnosis of ASD, which was authenticated in a study of medical record reviews of IAN registry participants $(n=116)$. Findings showed that $98 \%$ of participants were able to provide the valid documentation of the diagnosis of ASD (Daniels et al., 2011). The surveys were web-based via Survey Monkey (www.surveymonkey.com). Participation was voluntary. Inclusion criteria included being an English-speaking parent of one or more children with a diagnosis of ASD (Autism, PDD-NOS, or Asperger's), with Internet access, and residing in the United States. There were no specific exclusion criteria.

\section{Instruments}

\section{Parenting Stress Scale: Autism}

Parenting stress was measured with the Parenting Stress Scale: Autism (PSS:A) (Phetrusuwan \& Miles, 2009). The 28-item scale captures stressful experiences in four subscales: (1) the behaviors and communication subscale addresses the stress of dealing with behaviors in public, helping the child learn to be with other people, and how to best communicate; (2) the parental care giving stress subscale relates to feelings about the child not wanting to be touched, eating problems, sleep problems, and bathing and dressing; (3) the advocating for the child's needs subscale has questions related to the stress of communicating with schools and health care professionals about the child's special needs; and (4) the personal and family life subscale refers to the stress of financial problems, siblings, and finding time for one's own activities. Each item is rated on a 5-point Likert scale ( $1=$ not stressful, to $5=$ extremely stressful). Scores range from 0-140. Higher scores represent more stress. Content and face validity of the PSS:A was established with parents and professionals and a principal components factor analysis was done (Phetrusuwan \& Miles, 2009). The Cronbach alpha was .94 in the present study. 


\section{Feetham Family Functioning Survey}

Family functioning was measured with the Feetham Family Functioning Survey (FFFS; Feetham \& Humenick, 1982). The survey addresses three areas of family functioning: (1) family and broader social units, such as schools, (2) within family division of labor, and (3) reciprocal relationships between family members. These areas are assessed and supported through factor analysis (Feetham \& Humenick, 1982). A discrepancy score (D) is determined for each item. The difference between the "what is" and "what should be" scores for each item is converted to an absolute score (1 represents "little discrepancy" and 7 represents "much discrepancy"). Next, the discrepant scores from each item are summed for an instrument score. The total D scores can range from 0-126. A high score represents a higher discrepancy between the respondents' perception of "what is" from their perception of "what should be." In the present study the FFFS had a Cronbach alpha of .92. Two questions on the FFFS allow for write-in responses. The questions were: (1) What is most helpful to you now? and (2) What is least helpful to you now?

Data Quality

Participants were instructed to complete the survey for themselves, not on behalf of someone else, and complete the survey only once. A visual inspection of the data did not discover any pattern of contradictory responses.

\section{Procedure}

Approval for the study was obtained from the Institutional Review Boards at both the University and the Children's Hospital. Participants accessed the electronic versions of the questionnaires on-line along with a description of the study, and were provided with the researcher's e-mail address. The participant read the cover letter and accepted the terms described on a form (i.e., informed consent was obtained). Participants then completed the demographic form and each questionnaire.

Confidentiality was maintained; no personal identifiers appeared on the questionnaire. Participants created their own numeric identifier by entering (1) gender, (2) month of child's birthday, (3) month of spouse's birthday, (4) initial of first name, and (5) state of residence. The consent wording instructed the participant to ask their spouse/partner to fill out a set of questionnaires. Spouses who completed a set of questionnaires were matched based on the numeric identifiers. The data were entered by the participant and automatically entered into an Excel spread sheet. The Excel file was imported to SPSS 16.0.

\section{Data Analysis}

The Kruskal-Wallis test was used to compare the medians among the three groups of parents of children with ASD. Data from the two questions on the FFFS allowing for write in responses on: (1) What is most helpful to you now? and (2) What is least helpful to you now? were exported to a Microsoft Word document and were used to clarify the interpretation of the quantitative findings.

\section{RESULTS}

Demographics for the female parents and the children are summarized in Table 1. The majority of the mothers were white, college educated, and married. The majority of the children were white males with autistic disorder. Mothers in the three groups were married/non-survey participating spouse $(n=$ 
$164,63.5 \%)$, married/participating spouse $(n=61,22.3 \%)$, and non-married with no participating partner $(n=36,13.1 \%)$.

TABLE 1 Sample Characteristics $(N=261)$

\begin{tabular}{|l|l|l|l|}
\hline$n$ (\%) & & & \\
\hline Sex of Child & & & \\
\hline Male & $200(77)$ & & \\
\hline Female & $53(20.4)$ & & \\
\hline Missing & $8(2.2)$ & & \\
\hline Diagnosis of Child & & & \\
\hline Autism & $134(51.7)$ & & \\
\hline PDD-NOS & $61(23.5)$ & & \\
\hline Asperger's & $58(22.3)$ & & \\
\hline Race: Female Parent & & & \\
\hline White & $236(90)$ & & \\
\hline Hispanic & $15(5.3)$ & & \\
\hline Asian & $5(1.6)$ & & \\
\hline African-American & $2(0.9)$ & & \\
\hline Other & $3(1.9)$ & & \\
\hline Marital Status of Parent & & & \\
\hline Married & $213(81.5)$ & & \\
\hline Divorced & $21(7.8)$ & & \\
\hline Separated & $10(3.4)$ & & \\
\hline Single & $9(3.1)$ & & \\
\hline Widowed & $3(0.6)$ & & \\
\hline Other & $5(1.9)$ & & \\
\hline Education of Parent & & & \\
\hline Graduate degree & $67(25.8)$ & & \\
\hline College graduate & $116(44.3)$ & & \\
\hline Some college & $70(26.8)$ & & \\
\hline High school graduate & $31(11.8)$ & & \\
\hline Less than high school graduate & $21(0.08)$ & & \\
\hline & Mean (yrs.) & Range (yrs.) & SD \\
\hline Age of Mother (yrs.) & 39.2 & $29-69$ & \\
\hline Age of Child (yrs.) & 7.8 & $2-24$ & \\
\hline Number of children at home & 2.2 & 1.5 & \\
\hline & & & \\
\hline
\end{tabular}

Results for the first research questions are found in Table 2. Mothers in the married/non-survey participating spouse ( $n=164,63.5 \%$ ) had lower stress (median $=4$; range: $1-5 ; p=.02$ ) for Question 5, responding to child tantrums, than mothers in the other two groups (both had a median of 5; range: 15). For Question 28, work demands and child care responsibilities, the non-married mothers with no participating partner had higher stress (median $=5$; range: $1-5 ; p=.01$ ) than mothers in the other two groups (both had a median $=4$; range: $1-5$ ).

\section{TABLE 2 Differences in Medians of Parenting Stress Items}




\begin{tabular}{|c|c|c|c|c|}
\hline & $\begin{array}{l}\text { Married/Non- } \\
\text { Dyad }\end{array}$ & $\begin{array}{l}\text { Non-Married/ } \\
\text { Non-Dyad }\end{array}$ & Married/Dyad & \\
\hline & $(n=164)$ & $(n=61)$ & $(n=36)$ & \\
\hline Parenting Stress Scale Questions & Median $^{1}$ (range) & Median $^{1}$ (range) & Median $^{1}$ (range) & Sig \\
\hline 1. Managing my child's behaviors in public & $4(1-5)$ & $4(1-5)$ & $4(2-5)$ & .33 \\
\hline $\begin{array}{l}\text { 2. Helping my child learn how to be with } \\
\text { other children }\end{array}$ & $4(1-5)$ & $4(2-5)$ & $4(1-5)$ & .66 \\
\hline $\begin{array}{l}\text { 3. Learning how to best communicate with } \\
\text { my child }\end{array}$ & $4(1-5)$ & $4(1-5)$ & $4(1-5)$ & .28 \\
\hline $\begin{array}{l}\text { 4. Helping my child communicate with } \\
\text { others adequately }\end{array}$ & $4(2-5)$ & $4(2-5)$ & $4(2-5)$ & .29 \\
\hline $\begin{array}{l}\text { 5. Trying to figure out what my child needs } \\
\text { or wants if he/she is having a tantrum }\end{array}$ & $4(1-5)^{*}$ & $5(1-5)$ & $5(1-5)$ & $.02 *$ \\
\hline $\begin{array}{l}\text { 6. Managing my child's demanding } \\
\text { behaviors, mood changes, and upset } \\
\text { feelings }\end{array}$ & $5(1-5)$ & $4.5(1-5)$ & $5(1-5)$ & .19 \\
\hline $\begin{array}{l}\text { 7. Communicating clearly to the school or } \\
\text { day care or babysitters about my child's } \\
\text { special needs }\end{array}$ & $4(1-5)$ & $4(2-5)$ & $4(1-5)$ & .13 \\
\hline $\begin{array}{l}\text { 8. Communicating with health care } \\
\text { professionals about my child's behavior and } \\
\text { his/her needs }\end{array}$ & $3(2-5)$ & $4(2-5)$ & $4(2-5)$ & .56 \\
\hline $\begin{array}{l}\text { 9. Making sure my child is getting the } \\
\text { appropriate help in school }\end{array}$ & $4(1-5)$ & $4(2-5)$ & $4(1-5)$ & .71 \\
\hline $\begin{array}{l}\text { 10. Helping family members understand my } \\
\text { child's condition and related needs }\end{array}$ & $4(2-5)$ & $4.5(1-5)$ & $4(1-5)$ & .41 \\
\hline $\begin{array}{l}\text { 11. Feeling like my child doesn't want to be } \\
\text { cuddled, touched, or held as much as I'd like }\end{array}$ & $2(1-5)$ & $2(2-5)$ & $2(1-5)$ & .36 \\
\hline $\begin{array}{l}\text { 12. Dealing with my child's problems } \\
\text { related to eating }\end{array}$ & $3(1-5)$ & $3(1-5)$ & $4(1-5)$ & .68 \\
\hline $\begin{array}{l}\text { 13. Managing my child's problems with } \\
\text { sleep }\end{array}$ & $3(1-5)$ & $3(1-5)$ & $3(1-5)$ & .26 \\
\hline $\begin{array}{l}\text { 14. Handling my child's problems related to } \\
\text { bathing and dressing }\end{array}$ & $3(1-5)$ & $3(1-5)$ & $3(1-5)$ & .66 \\
\hline $\begin{array}{l}\text { 15. Knowing how to appropriately discipline } \\
\text { my child }\end{array}$ & $4(1-5)$ & $4(1-5)$ & $4(1-5)$ & .08 \\
\hline $\begin{array}{l}\text { 16. Overcoming my feelings of } \\
\text { protectiveness toward my child }\end{array}$ & $4(1-5)$ & $4(1-5)$ & $4(1-5)$ & .64 \\
\hline $\begin{array}{l}\text { 17. Trying to keep my child's life as normal } \\
\text { as possible }\end{array}$ & $4(1-5)$ & $4(1-5)$ & $4(2-5)$ & .21 \\
\hline $\begin{array}{l}\text { 18. Keeping my child on a regular routine at } \\
\text { home }\end{array}$ & $3(1-5)$ & $4(1-5)$ & $4(1-5)$ & .14 \\
\hline $\begin{array}{l}\text { 19. Helping other family members cope } \\
\text { with my child's behavior }\end{array}$ & $4(1-5)$ & $4(1-5)$ & $4(1-5)$ & .32 \\
\hline $\begin{array}{l}\text { 20. Dealing with the differences in opinion } \\
\text { about the care of my child with my } \\
\text { spouse/partner and or grandparents }\end{array}$ & $4(1-5)$ & $4(1-5)$ & $4(1-5)$ & .33 \\
\hline $\begin{array}{l}\text { 21. Balancing the needs of my child with } \\
\text { those of other family members }\end{array}$ & \begin{tabular}{|l|}
$4(1-5)$ \\
\end{tabular} & $4(1-5)$ & $4(2-5)$ & .37 \\
\hline
\end{tabular}




\begin{tabular}{|l|l|l|l|l|}
\hline $\begin{array}{l}\text { 22. Trying to keep life as normal as possible } \\
\text { despite my child's condition }\end{array}$ & $4(1-5)$ & $4(1-5)$ & $4(2-5)$ & .42 \\
\hline $\begin{array}{l}\text { 23. Trying to understand how much to } \\
\text { involve my child's siblings or other family } \\
\text { members in the care of my child }\end{array}$ & $4(1-5)$ & $4(1-5)$ & $4(1-5)$ & .25 \\
\hline $\begin{array}{l}\text { 24. Having financial problems related to my } \\
\text { child's problems }\end{array}$ & $4(1-5)$ & $4(1-5)$ & $5(1-5)$ & .36 \\
\hline $\begin{array}{l}\text { 25. Finding time for my own activities and } \\
\text { needs }\end{array}$ & $5(1-5)$ & $5(1-5)$ & $4.5(1-5)$ & .17 \\
\hline $\begin{array}{l}\text { 26. Difficulty giving myself permission to } \\
\text { take time for my own activities and needs }\end{array}$ & $5(1-5)$ & $5(1-5)$ & $5(1-5)$ & .71 \\
\hline $\begin{array}{l}\text { 27. Feeling that my child's problems control } \\
\text { my life }\end{array}$ & $4(1-5)$ & $5(2-5)$ & $5(1-5)$ & .31 \\
\hline $\begin{array}{l}\text { 28. Meeting the demands of my other work } \\
\text { responsibilities and care of my child }\end{array}$ & $4(1-5)$ & $5(1-5)^{*}$ & $4(1-5)$ & $.01^{*}$ \\
\hline
\end{tabular}

${ }^{1}$ Likert scale ( 1 = not stressful, 5 = extremely stressful).

*Statistically significant difference for one group compared to the other 2 groups

TABLE 3 Family Functioning Discrepancy Scores

\begin{tabular}{|c|c|c|c|c|}
\hline & $\begin{array}{l}\text { Married/Non- } \\
\text { Dyad }\end{array}$ & $\begin{array}{l}\text { Non-Married/ } \\
\text { Non-Dyad }\end{array}$ & Married/Dyad & \\
\hline & $(n=164)$ & $(n=61)$ & $(n=36)$ & \\
\hline Family Functioning Survey Questions & $\begin{array}{l}\text { Median } \\
\mathrm{D}^{1} \text { (range) }\end{array}$ & $\begin{array}{l}\text { Median } \\
\mathrm{D}^{1} \text { (range) }\end{array}$ & $\begin{array}{l}\text { Median } \\
\mathrm{D}^{1} \text { (range) }\end{array}$ & Sig \\
\hline $\begin{array}{l}\text { 1. Amount of discussion with your friends } \\
\text { regarding your concerns and problems }\end{array}$ & $1(0-6)$ & $2(0-6)$ & $1(0-5)$ & .66 \\
\hline $\begin{array}{l}\text { 2. Amount of discussion with your relatives } \\
\text { regarding your concerns and problems }\end{array}$ & $1(0-6)$ & $2(0-6)$ & $2(0-6)$ & .26 \\
\hline $\begin{array}{l}\text { 3. Amount of time you spend with your } \\
\text { spouse/partner }\end{array}$ & $2(0-6)$ & $2.5(0-6)$ & $2(0-6)$ & .76 \\
\hline $\begin{array}{l}\text { 4. The amount of discussion of your concerns } \\
\text { and problems with your spouse/partner }\end{array}$ & $2(0-6)$ & $2(0-6)$ & $1(0-6)$ & .40 \\
\hline $\begin{array}{l}\text { 5. Amount of time you spend with your } \\
\text { neighbors }\end{array}$ & $1(0-6)$ & $0(0-6)$ & $1(0-4)$ & .19 \\
\hline $\begin{array}{l}\text { 6. Amount of time you spend in } \\
\text { leisure/recreational activity }\end{array}$ & $2(0-6)$ & $2(0-6)$ & $2(0-6)$ & .80 \\
\hline $\begin{array}{l}\text { 7. Amount of help from your spouse/partner } \\
\text { with family tasks such as care of children, house } \\
\text { repairs, household chores, etc. }\end{array}$ & $1(0-6)$ & $3(0-6)$ & $1(0-6)$ & $.04^{*}$ \\
\hline $\begin{array}{l}\text { 8. Amount of help from your relatives with } \\
\text { family tasks such as care of children, house } \\
\text { repairs, household chores, etc. }\end{array}$ & $1(0-6)$ & $2(0-6)$ & $2(0-6)$ & $.03 *$ \\
\hline $\begin{array}{l}\text { 9. Amount of time you spend with health } \\
\text { professionals }\end{array}$ & $1(0-6)$ & $1(0-6)$ & $1(0-6)$ & .81 \\
\hline $\begin{array}{l}\text { 10. Amount of help from your friends with } \\
\text { family tasks such as care of children, house } \\
\text { repairs, household chores, etc. }\end{array}$ & $0(0-6)$ & $1(0-4)$ & $1(0-4)$ & .05 \\
\hline 11. Number of problems with your child(ren) & $2(0-6)$ & $2(0-6)$ & $2(0-6)$ & .07 \\
\hline
\end{tabular}




\begin{tabular}{|l|l|l|l|l|}
\hline $\begin{array}{l}\text { 12. Amount of time you spend with your } \\
\text { child(ren) }\end{array}$ & $1(0-6)$ & $1(0-4)$ & $1(0-4)$ & .60 \\
\hline 13. Amount of time your child(ren) miss school & $0(0-6)$ & $0(0-6)$ & $0(0-6)$ & $.001^{* *}$ \\
\hline $\begin{array}{l}\text { 14. Number of disagreements with your } \\
\text { spouse/partner }\end{array}$ & $1(0-6)$ & $3(0-6)$ & $1.5(0-6)$ & .21 \\
\hline 15. Amount of time you are ill & $1(0-6)$ & $1(0-6)$ & $1(0-6)$ & .41 \\
\hline $\begin{array}{l}\text { 16. Amount of time you spend doing housework } \\
\text { 17. Amount of time you miss work (including } \\
\text { housework) }\end{array}$ & $1(0-6)$ & $2(0-6)$ & $1(0-4)$ & .08 \\
\hline $\begin{array}{l}\text { 18. Amount of time your partner/spouse misses } \\
\text { work (including housework) }\end{array}$ & $0(0-6)$ & $1(0-6)$ & $1(0-6)$ & .08 \\
\hline $\begin{array}{l}\text { 19. Amount of emotional support from your } \\
\text { friends }\end{array}$ & $1(0-6)$ & $1(0-6)$ & $1(0-5)$ & .21 \\
\hline 20. Amount of emotional support from relatives & $2(0-6)$ & $2(0-6)$ & $2(0-6)$ & .78 \\
\hline $\begin{array}{l}\text { 21. Amount of emotional support from your } \\
\text { spouse/partner }\end{array}$ & $1(0-6)$ & $2.5(0-6)$ & $1(0-6)$ & .06 \\
\hline $\begin{array}{l}\text { 22. Amount of time your work routine is } \\
\text { disrupted (including housework) }\end{array}$ & $2(0-6)$ & $2(0-6)$ & $2(0-6)$ & .07 \\
\hline $\begin{array}{l}\text { 23. Amount of time your partner/spouse's work } \\
\text { routine is disrupted (including housework) }\end{array}$ & $1(0-6)$ & $0(0-6)$ & $1(0-6)$ & .79 \\
\hline $\begin{array}{l}\text { 24. Amount of satisfaction with your marriage } \\
\text { (relationship with spouse/partner) }\end{array}$ & $2(0-6)$ & $4(0-6)$ & $2(0-6)$ & .07 \\
\hline $\begin{array}{l}\text { 25. Amount of satisfaction with sexual relations } \\
\text { with your spouse/partner }\end{array}$ & $3(0-6)$ & $4.5(0-6)$ & $3(0-6)$ & .04 \\
\hline
\end{tabular}

${ }^{1}$ Discrepancy (D) is the difference between the "what is," and "what should be" scores for each item, converted to an absolute score ( 1 represents "little discrepancy" and 7 represents "much discrepancy"). D scores range from 0 (no difference) to 6 (the most difference).

${ }^{*} p<.05$ difference for one group compared to the other 2 groups

$* * p<.05$ by looking at the quartiles

Results for the second research questions are found in Table 3. Non-married mothers with no identified partner had more discrepancy in family functioning expectations (difference between how much help they perceived needing and how much they received) on three items of the FFFS. The first item (Question 7) assessed the amount of help from their spouse/partner with family tasks such as care of child(ren), house repairs, household chores etc. (median = 3; range: 0-6, compared to other groups' median = 2; range: $0-6$ ). The second item (Question 13) assessed expectations for the amount of time the child(ren) missed school (median $=0$; range: 1-6; $p=.001$ ). The third item (Question 25) assessed the amount of satisfaction with sexual relations with a spouse/partner (median $=4.5$; range: 0-6, compared to other groups' median = 3; range: 0-6).

Married mothers without participating spouses had more discrepancy in family functioning expectations (difference between how much help they perceived needing and how much they received) on one item (Question 8) of the FFFS. This item assessed expectations of the amount of help from relatives with family tasks, such as taking care of the children, house repairs, household chores, etc. (median $=1$; range: $0-6$, compared to the other groups' median $=2$; range: $0-6 ; p=.03$ ). 


\section{DISCUSSION}

The present study is the first to develop research questions to discern if there were differences for mothers when fathers chose not to participate in an autism research study. In particular, the differences assessed were the stressors, expectations, and available supports for mothers grouped according to marital status and spouse/partner survey participation. Results showed differences in select individual items of the PSS:A and the FFFS, which are presented below.

The first research question asked if married mothers whose male spouse did not participate in the study have lower stress than married mothers whose spouse did participate in the study, or than the unmarried mothers with no participating partner. This category of mothers ( $n=164,63.5 \%$ ) was the largest and represents a fundamental problem of the difficulty of recruiting both mothers and fathers for autism research studies. Spouses (fathers) may have no discretionary time to complete surveys. Conversely, fathers who do not participate in the study may not participate in other decisions about the day-to-day care of the child with ASD; there is no way to know from the data collected in the present study. Future studies attempting to recruit both parents could ask the participating spouse their perception for the lack of spouse participation.

The results showed that the married mothers, whose male spouse did not participate in the study, had lower perceived stress for responding to child tantrums than the other two grouping of mothers. Past literature shows that it is stressful for mothers to explain actions to a spouse/partner, so not having to explain the actions might explain this finding of lower stress (Knafl \& Deatrick, 2003; Smith et al., 2010). Although we know that challenging child behaviors are stressful for mothers (Estes et al., 2009; Hastings et al., 2005; Phetrasuwan \& Miles, 2009; Tobing \& Glenwick, 2006), negotiating with a spouse about how to react to a child's behaviors is also a source of stress. The stress is the result of different expectations between spouses about how best to react to the behaviors and could lead to poor maternal mental health (Knafl \& Deatrick, 2003).

Stress and coping theory, which frames the study, predicts mothers will use various strategies to cope with stress. Mothers of children with ASD may isolate themselves to cope with the risk of children acting out in public (Gray, 2003). Mothers may not take a child out in public for fear of having to deal with a child's tantrums. In the present study, one mother wrote on the FFFS that what she finds most helpful is "ignoring or staying away from people that aren't helpful or create more unneeded stress." The reaction may be a form of coping that could lead to maternal isolation, placing mothers at risk for poor mental health (Lazarus, 1999). Conversely, it could be that the mothers turn to more supportive people, if they can be found elsewhere. Regardless, the wide discrepancy in expectations (between what is and what should be) about desire for assistance from neighbors is a source of concern for the mothers, and is an important finding in this study. Many other items on the survey did not meet statistical significance, which speaks to the mothers' resilience. Regardless, health care providers cannot assume that the mothers of children with ASD have access to support (e.g., supportive neighbors); some mothers may need to find supports on their own and, as such, assessment of supports and assistance with finding other supports may be necessary.

A second research question asked if married mothers whose male spouses participated in the study had a higher discrepancy in family functioning than the married mothers whose spouses did not 
participate in the study, or than the unmarried mothers that did not identify a partner helping them care for the child(ren). Married mothers whose male spouses participated in the study had a discrepancy in expectations for "what is" and "what should be" for help from relatives with family tasks (e.g., child care, house repairs, chores). This finding means that the mothers expected more help than what they were getting. The mothers did not perceive that their needs for the functions of the family were being met. Based on literature, this finding may be explained by mothers' traditional role of caregiver and of doing majority of care (Smith et al., 2010). Some married mothers were not feeling supported by their partner/husband and families in the present study. Free text comments by one of the mothers may explain the discrepancy in their expectations, as she describes what helps her the least: "Not being consistent with my son's behavior plan; doesn't discipline same as I do." Clearly, parents may have differences in expectations, and these differences are sources of stress. However, past studies found that improved marital quality was associated with lower parenting stress (Kersh et al., 2006; Simon-Tov \& Kaniel, 2010). Therefore, the dynamics of being a married mother, without a supportive spouse (for whatever reason) could contribute to parenting stress.

The non-married group of mothers had no participating partner. They reported more parenting stress for meeting the demands of other work responsibilities and care of the child. This finding is most likely related to the difficult time a single parent of a child with ASD has finding child care or help from other family members. A key finding in the present study is that single parents without an identified partner benefit from the support that school attendance offers. Without a reliable school that can care for a child with ASD's behavior problems, and without a reliable system of family and friends, a parent may need to stay home with the child and miss work and leisure opportunities. Staying home from work can have both financial and mental health repercussions for mothers of children with ASD.

In the present study, parents report that their family (mother, parents, paternal grandparents, in-laws) may not help or show support. Support may be lacking when others do not understand ASD and do not know how to care for children with ASD. One mother wrote that "our families are constantly telling us she will get over it" and another wrote, "the neighbors just decided they didn't want to deal with our son." Literature shows that school is an important source of maternal support when there are no close family members to help (Luong, Yoder, \& Canham, 2009). However, the accessibility of appropriate school or education is shown in the literature to be a source of dissatisfaction second only to difficulties with obtaining the diagnosis of ASD (Renty \& Roeyers, 2006). Children with ASD may be sent home because of their challenging behaviors and requirement for vigilance from staff (Larson, 2010), which is both time consuming and mentally exhausting. In the present study, free text comments on the FFFS about what helps the most included: "school as respite," "fantastic school system," and "teachers." Free text comments about what helps the least included: "the kids having shortened or no school," "time away from school," and "transitioning semesters at school." School is a helpful support for families, and health care professionals are encouraged to facilitate successful partnerships between schools and families to assure attendance.

\section{Implications for Nurses}

Assessment of both parents' perceptions of family supports should be part of the nurse's care of children with ASD. Fathers' lack of participation in research is a lost opportunity to identify sources of stress and supports. In fact, nurses play a pivotal role in promoting the mental health of family 
members, by assessing both parents' satisfaction with family functioning. Mentally healthy parents are in the best position to make informed decisions in planning and in selecting treatments for their children with ASD. Parents perceive less stress and have less depression when they feel that help is available from understanding, close, or significant persons in their life (Renty \& Roeyers, 2006; SimonTov \& Kaniel, 2011; Tobing \&Glenwick, 2006). Parents may benefit from knowing that it is normal to have differences in expectations about how much help is needed compared to how much help one receives related to meeting the needs of a child with ASD. Particularly in the case of parents of children with ASD, continued frustration about differences in expectations and reality may negatively impact the child and could reduce the impact of education and other treatment efforts.

During assessments, health care providers should anticipate differences in perceived parenting stress from challenging child behaviors, and in family functioning expectations based on relationship variables such as marital status. Assessments should address how the family's needs are being met related to help with child care and reliable school attendance. Single mothers without identified partners (that help with child care) may need assistance with finding safe child care and may rely on schools as a source of support.

The findings in the study have implications for planning for other supports for families of children with ASD. Mothers who take children with severe forms of ASD in public face challenges and if they perceive that their child's behavior is too challenging to take the child out in public, they become at risk for isolating behaviors. In public, people may stare, make remarks, or fail to understand any accidents or behaviors that may occur. Mothers may not know how to react to onlookers' negative reactions and may benefit from parent training on how to react. Local autism societies offer parent training. Parent to parent (www.p2pusa.org) is another source of support. Other resources include the Autism Society of America (www.autism-society.org), Autism Speaks (www.autismspeaks.org; which also includes resources for schools), and the National Autistic Society (www.autism.org.uk). National organizations can direct families to local organizations.

\section{Limitations}

The study reports on data that is part of a larger cross sectional study with self-report data collection. The ASD diagnosis for the child was by parent report and was not confirmed for this study. Additionally, it is possible that a parent did not ask a spouse to participate in the study. There was an absence of diversity in the sample, and a wide variety of child ages. The majority of the mothers who participated indicated that they were white, college educated, and married, which may limit the transferability of the findings to non-white mothers.

\section{CONCLUSION}

The results of this study revealed the vulnerability of single mothers due to unmet expectations about support from relatives and neighbors with child care, household repairs, chores, and the amount of time their child missed school. However, the results showed that the married mothers, whose male spouse did not participate in the study, had lower perceived stress for responding to child tantrums than the other two grouping of mothers. Negotiating with a spouse (father of child) on how to deal with a child's challenging behaviors is stressful for mothers. Research studies that only report on mothers, without referencing whether or not their spouse participates in day-to-day decisions 
regarding treatments and strategies for dealing with challenges such as tantrums, do not fully represent the nature of the mothers' stress. Further research is needed with a more diverse sample of participants. A strategy to recruit fathers of children with ASD for research and to identify the reasons for both parents not participating in studies also is needed. Fathers who are primary caregivers may have wives who do not participate. In addition, studies that test supportive interventions for a child's challenging behaviors and child care needs would add to the state of the science in this growing population of families of children with ASD.

Declaration of interest: The authors report no conflicts of interest. The authors alone are responsible for the content and writing of the paper.

\section{REFERENCES}

Agency for Healthcare Research and Quality. (2011). Research reviews: Comparative effectiveness of therapies for children with Autism Spectrum Disorders. U.S. Department of Health and Human Services, Agency for Healthcare Research and Quality. Retrieved from http://www.effectivehealthcare. ahrq.gov/ehc/products/106/651/Autism Disorder execsumm.pdf

Allik, H., Larsson, J.-O., \& Smedje, H. (2006). Health-related quality of life in parents of school-age children with Asperger Syndrome or high-functioning autism. Health \& Quality of Life Outcomes, 4, 1.

American Psychiatric Association. (2000). Diagnostic and statistical manual of mental disorders (4th ed., text rev.). Washington, DC: Author.

Autism and Developmental Disabilities Monitoring Network Surveillance Principal Investigators. (2012). Prevalence of autism spectrum disorders-autism and developmental disabilities monitoring network, 14 sites, United States, 2008. MMWR Surveillance Summary, 61(3), 1-19.

Brobst, J., Clopton, J., \& Hendrick, S. (2009). Parenting children with Autism Spectrum Disorders: The couple's relationship. Focus on Autism and Other Developmental Disabilities, 24(1), 38-49.

Cohen, S., Underwood, L., \& Gottlieb, B. (Eds.) (2000). Social support measurement and intervention. Oxford, England: Oxford University Press.

Daniels, A. M., Rosenberg, R. E., Anderson, C., Law, J. K., Marvin, A. R., \& Law, P. (2011). Verification of parent report of child autism spectrum disorder diagnosis to a web-based autism registry. Journal of Autism and Developmental Disabilities, 42, 25-265.

Easter Seals. (2009). Easter Seals Living with Autism study. Retrieved from http://www.easterseals.com/site/PageServer?pagename=ntlc8_living_with_ autism_study_home

Estes, A., Munson, J., Dawson, G., Koehler, E., Zhou, X., \& Abbott, R. (2009). Parenting stress and psychological functioning among mothers of preschool children with autism and developmental delay. Autism, 13(4), 375-387.

Feetham, S., \& Humenick, S. (1982). The Feetham Family Functioning Survey. In S. Humenick (Ed.), Analysis of current assessment strategies in the health care of young children and childbearing families (pp. 259-268). New York, NY: Appleton-Century Crofts.

Gray, D. E. (2003). Gender and coping: The parents of children with high functioning autism. Social Science \& Medicine, 56(3), 631-642.

Hallmayer, J., Cleveland, S., Torres, A., Philips, J., Cohen, B., Torigoe, T., and Risch, N. (2011). Genetic heritability and shared environmental factors among twin pairs with autism. Archives of General Psychiatry. doi:10.1001/archgenpsychiatry.2011.76 
Hastings, R., Kovshoff, H., Ward, N., Degli Espinosa, F., Brown, T., \& Remington, B. (2005). Systems analysis of stress and positive perceptions in mothers and fathers of preschool children with autism. Journal of Autism \& Developmental Disorders, 35(5), 635-644.

Herring, S., Gray, J., Taffe, B., Sweeny, D., \& Einfeld, S. (2006). Behaviour and emotional problems in toddlers with pervasive developmental disorders and developmental delay: Associations with parental mental health and family functioning. Journal of Intellectual Disability Research, 50(12), 874-882.

Johnson, N., Frenn, M., Feetham, S., \& Simpson, P. (2011). Autism Spectrum Disorder: Parenting stress, family functioning and health related quality of life. Family, Systems, \& Health, 29(3), 232-252.

Kersh, J., Hedvat, T. T., Hauser-Cram, P., \& Warfield, M. E. (2006). The contribution of marital quality to the well-being of parents of children with developmental disabilities. Journal of Intellectual Disability Research, 50(12), 883-893.

Knafl, K. A., \& Deatrick, J. A. (2003). Further refinement of the family management style framework. Journal of Family Nursing, 9(3), 232-256.

Lakey, B. (2010). Social support: Basic research and new strategies for intervention. In J. E. Maddux \& J. P. Tangney (Eds.), Social psychological foundations of clinical psychology (pp. 177-194). New York, NY: Guilford.

Lakey, B., \& Cohen, S. (2000). Social support theory and measurement. In S. Cohen, L. Underwood, \& B. Gottlieb (Eds.), Social support measurement and intervention (pp. 29-52). Oxford, England: Oxford University Press.

Lakey, B., \& Cronin A. (2008). Low social support and major depression: Research, theory and methodological issues. In K. S. Dobson \& D. Dozois (Eds.), Risk factors for depression (pp. 385408). San Diego, CA: Academic.

Larson, E. (2010). Ever vigilant: Maternal support of participation in daily life for boys with autism. Physical Occupational Therapy in Pediatrics, 30(1), 16-27.

Lazarus, R. S. (1999). Stress and emotion: A new synthesis. New York, NY: Springer.

Little, L. (2002). Differences in stress and coping for mothers and fathers of children with Asperger's syndrome and non-verbal learning disorders. Pediatric Nursing, 28, 565-570.

Luong, J., Yoder, M., \& Canham, D. (2009). Southeast Asian parents raising a child with autism: A qualitative investigation of coping styles. The Journal of School Nursing, 25(3), 222-229.

Macfadyen, A., Swallow, V., Santacroce, S., \& Lambert, H.(2011). Involving fathers in research. Journal for Specialists in Pediatric Nursing, 16(3), 216-219.

McCubbin, H., \& Thompson, A. (Eds.). (1991). Family assessment inventories for research and practice (2nd ed.). Madison, WI: University of Wisconsin.

McCubbin, H. I., Thompson, A., \& McCubbin, M. A. (1996). Family assessment: Resiliency coping and adaptation-inventories for research and practice. Madison, WI: University of Wisconsin System.

Phetrasuwan, S., \& Miles, M. (2009). Parenting stress in mothers of children with autism spectrum disorders. Journal of Pediatric Nursing, 14(3), 157-165.

Rao, P. A., \& Beidel, D. C. (2009). The impact of children with high-functioning autism on parental stress, sibling adjustment, and family functioning. Behavior Modification, 33(4), 437-451.

Renty, J., \& Roeyers, H. (2006). Satisfaction with formal support and education for children with autism spectrum disorder: The voices of the parents. Child: Care, Health and Development, 32(3), 371385.

Roberts, C., \& Feetham, S. (1982). Assessing family functioning across three areas of relationships. Nursing Research, 31(4), 231-235. 
Rutter, M. (2005). Incidence of autism spectrum disorders: Changes over time and their meaning. Acta Paediatric, 94(2), 2-15.

Siman-Tov, A., \& Kaniel, S. (2011). Stress and personal resource as predictors of the adjustment of parents to autistic children: A multivariate model. Journal of Autism and Developmental Disorders, 41(7), 879-890. doi:10.1007/s10803-010-1112-x

Smith, L. E., Hong, J., Seltzer, M. M., Greenberg, J. S., Almeida, D. M., \& Bishop, S. L. (2010). Daily experiences among mothers of adolescents and adults with autism spectrum disorder. Journal of Autism and Developmental Disorders, 40(2), 167-178.

Tobing, L., \& Glenwick, D. (2006). Predictors and moderators of psychological distress in mothers of children with pervasive developmental disorders. Journal of Family Social Work, 10(4), 1-22. 